\title{
Analysis of The Effect of Healthy and Healthy Life and Health (PHBS) Behavior of Tuberculosis Events
}

\author{
Eko Purwanto ${ }^{1}$, Zufra Inayah, SKM., M.Kes ${ }^{2}$ \\ ${ }^{1}$ College student, Department of Public Health, Health Faculty, Gresik Muhammadiyah University, Indonesia \\ ${ }^{2}$ Lecturer Department of Public Health, Health Faculty, Gresik Muhammadiyah University, Indonesia
}

\begin{tabular}{l}
\hline Article Info \\
\hline Article history: \\
Received Jun 9, 2019 \\
Revised Nov 20, 2019 \\
Accepted Feb 11, 2020 \\
\hline
\end{tabular}

\section{Keywords:}

PHBS,

Healthy house,

Transmission, Lung TB

\begin{abstract}
Tuberculosis is globally classified as a global public health Emergency. Tuberculosis is an infectious disease caused by the bacteria Mycobacterium tuberculosis. East Java is ranked 2nd after West Java in TB case finding and Sidoarjo Regency is a District with the $3^{\text {rd }}$ CDR achievement in East Java. The magnitude of public health problems due to Tuberculosis so that WHO provides an ultimatum with global warnings, in the Millennium Development Goals agreement aimed at freeing the world from Tuberculosis by 2050 clean and healthy life. This research was conducted with the aim of knowing how much influence the healthy home and clean and healthy living behavior on transmission and contracting TB disease.

In this study using multivariate analysis by means of multiple linear regression test with a sample of 388 families where the method of sampling by means of Probability sampling is a sampling technique that provides equal opportunities for each element (member) of the population to be selected as sample members. The method of taking with simple random sampling is a technique to get samples that are directly carried out on the sampling unit [1], analysis with the Multiple Linear Regression test by looking at the coefficient of determination (Ajusted) and the value of the beta regression $(\beta)$. Tests carried out using a significant level $<0.05 \%$ or $5 \%$.

The results of this study from households whose homes did not meet health requirements were found to be as much as $18.0 \%$ which in one year there were family members suffering from tuberculosis and in households that did not apply Clean and Healthy Behavior (PHBS) there were $18.8 \%$ in 1 year there are family members who suffer from tuberculosis.
\end{abstract}

Copyright (c) 2020 University Muhammadiyah of Gresik. All rights reserved.

\section{Corresponding Author:}

Eko Purwanto,

College student, Department of Public Health, Health Faculty,

Gresik Muhammadiyah University,

Street Sumatera 101 Gresik Kota Baru (GKB), Gresik - 61121.

Email: ekopurwanto@gmail.com 


\section{INTRODUCTION}

In tackling TB the world has a high weight. According to WHO, Indonesia's burden in controlling tuberculosis is 3, namely: TB cases are number 3 in the world, namely 1 . There are around 889,000 people with 319 TBC per 100,000 population, while the burden of TB cases in Indonesia is 2. The burden of drug resistant TB 23,000 and 3 . The burden TB-HIV 36,000 sufferers or 14 / 100.000 population. In 2017 there were 442,000 TB cases recorded in the program, of which there were an estimated 8,60015,000 MDR / RR TB, (estimated 2.4\% of new cases and 13\% of TB patients treated previously). But the coverage that was treated was around $27.36 \%$. Tuberculosis is globally classified as a global public health Emergency. Tuberculosis is an infectious disease caused by the bacteria Mycobacterium tuberculosis. There are several species of Mycobacterium, including: M. Tuberculosis, M. Africanum, M. Bovis, M. Leprae, etc. Also known as Acid Resistant Bacteria (BTA). The group of Mycobacterium bacteria besides Mycobactrerium tuberculosis which can cause interference with the airways is known as MOTT (Mycobacterium Other Than Tuberculosis) which sometimes can interfere with the diagnosis and treatment of tuberculosis [2].

In 2018 East Java was ranked second after West Java in TB case finding with the number of findings recorded as many as 57,503 new patients found and treated [3].

The magnitude of public health problems caused by Tuberculosis so that WHO provides an ultimatum with global warnings, in the Millennium Development Goals agreement aimed at freeing the world from Tuberculosis in 2050. Therefore the Government and related agencies continue to try to reduce the number of tuberculosis disease outbreaks. The Sidoarjo Regency Government uses the DOTS (Directly observed treatment short course) strategy to reduce the rate of tuberculosis in Sidoarjo Regency. The DOTS strategy is an effective strategy to stop the spread of tuberculosis [4].

Researchers raised the house factor and clean and healthy life behavior because according to $\mathrm{H}$. L Blum regarding health status, there are four factors which are determinants of health problems. The four factors consist of behavior / lifestyle (life style), environmental factors (social, economic, political, cultural), health service factors (type of coverage and quality) and genetic factors (heredity). These four factors interact with each other which affects individual health and community health status. Among these factors, human behavior is the biggest and most difficult determinant factor, followed by environmental factors. This is due to more dominant behavioral factors compared to environmental factors because the human environment is also strongly influenced by people's behavior. Based on Blum theory, the value of its interpretation of the environment is 45\%, Behavior 35\%, Health Services 15\%, Descendants 5\%.

\section{RESEARCH METHOD}

This type of research is observational analytic. This study uses multivariate analysis by means of multiple linear regression testing. This research is intended to obtain data and facts from existing problems and to find information and clear picture of the influence of physical environment factors of a healthy home and clean and healthy living behavior (PHBS) on the outbreak of tuberculosis in Sidoarjo Regency.

Population is a group of elements or elements which are the object of research. The population can be in the form of institutions, individuals, groups, documents or concepts [5]. 
The population of this research is Bulu Sidokare village in the Sekardangan Community Health Center in Sidoarjo District in Sidoarjo Regency, with a total of 12,078 households of households.

Sampling (sampling) is the process of selecting a sufficient number of elements from the population, so that research on the sample and understanding of the nature or characteristics will enable us to generalize these characteristics or characteristics to the population element [6]. The sample is part of the number and characteristics possessed by the population [7]. A good sample, the conclusion of which can be imposed on the population, is a sample that is representative or that can describe the characteristics of the population. In this study sampling by means of Probabiliti sampling is a sampling technique that provides equal opportunities for each element (member) of the population to be selected as sample members. The method of taking with simple random sampling is a technique to get samples that are directly carried out at the sampling unit [8].

Rounded up, the minimum sample size of 388 populations at a margin of error of $0.05 \%$ is 388 populations. The sample of this research is the number of households in the area of Sekardangan Health Center, Sidoarjo District, which is 388 households.

\section{RESULTS AND DISCUSSIONS}

Sidoarjo Regency is divided into 18 subdistricts and there are 26 Puskesmas, while the Sekardangan Puskesmas is aministratif located in the Sidoarjo District area. In the Sidoarjo sub-district is divided into 3 Puskesmas, namely: Sidoarjo Puskesmas, Urangagung Puskesmas and Sekardangan Puskesmas. In 2018 the discovery of TB patients in Sekardangan Health Center there were 73 reported cases in the Regency (CDR 55.49\% of the estimated incident TB cases). The Sekardangan Community Health Center has 6 villages that have become its target villages, while the population distribution is as follows:

\begin{tabular}{clrrrr} 
No & \multicolumn{1}{c}{ Village } & $\begin{array}{c}\text { An area } \\
\left(\mathbf{k m}^{\mathbf{2}} \mathbf{)}\right.\end{array}$ & $\begin{array}{c}\text { Total } \\
\text { population }\end{array}$ & $\begin{array}{c}\text { Number of } \\
\text { Households }\end{array}$ & $\begin{array}{c}\text { Average life / } \\
\text { household }\end{array}$ \\
1 & Sekardangan & 8.239 & 7.529 & 2.102 & 3,58 \\
2 & Celep & 528 & 5.760 & 1.662 & 3,47 \\
3 & Pucang anom & 4.037 & 5.057 & 1.756 & 3,45 \\
4 & Bulu sido kare & 9.700 & 10.331 & 2.997 & 3,45 \\
5 & Gebang & 12.229 & 7.528 & 2.148 & 3,50 \\
6 & Rangkah kidul & 2.584 & 4.834 & 1.423 & 3,42 \\
& Totals & 37.313 & 42.036 & 12.078 & 3,48
\end{tabular}

a. Results of assessment of respondent characteristics

1) Age of Respondents

Based on research conducted on 388 respondents who were sampled obtained the following results.

\begin{tabular}{crrcc} 
No. & Age Group (years) & Totals & Percentage (\%) \\
\hline 1. & $20-30$ & & 47 & 12,11 \\
2. & $30-40$ & & 106 & 27,32 \\
3. & $40-50$ & & 112 & 28,87 \\
4. & $>50$ & Totals & 123 & 31,70 \\
& & Tots & $\mathbf{3 8 8}$ & $\mathbf{1 0 0}$
\end{tabular}




\section{2) Gender of the respondent}

Distribution of the characteristics of respondents who answered the questionnaire in the area of Sekardangan Community Health Center according to male gender $157(40.46 \%)$ and female gender 231 respondents $(59.54 \%)$.

3) Education of respondents

$\begin{array}{clccc}\text { No. } & & \text { Level of education } & \text { Totals } & \text { Percentage (\%) } \\ \text { 1. } & \text { SD } & & 61 & 15,72 \\ \text { 2. } & \text { SMP } & & 96 & 24,74 \\ \text { 3. } & \text { SMA } & & 187 & 48,20 \\ \text { 4. } & \text { S1 } & \text { Totals } & 44 & 11,34 \\ & & \text { T88 } & \mathbf{3 8 0}\end{array}$

b. Healthy house assessment results

\begin{tabular}{llcc} 
No. & \multicolumn{1}{c}{ Leadership Style } & Totals & Percentage (\%) \\
1. & Healthy Home & 219 & 56,4 \\
2. & Unhealthy home & 169 & 43,6 \\
& $\quad$ Totals & $\mathbf{3 8 8}$ & $\mathbf{1 0 0 , 0}$
\end{tabular}

c. Results of a Clean and Healthy Behavior assessment

\begin{tabular}{clcc} 
No. & \multicolumn{1}{c}{ Leadership Style } & Totals & Percentage (\%) \\
1. & Do PHBS & 202 & 52,1 \\
2. & Not Doing PHBS & 186 & 47,9 \\
& $\quad$ Totals & $\mathbf{3 8 8}$ & $\mathbf{1 0 0 , 0}$
\end{tabular}

\section{d. TB incident}

\begin{tabular}{cccc} 
No. & Leadership Style & Totals & Percentage $(\%)$ \\
1. & There are sick in the last 1 year & 73 & 18,8 \\
2. & No one has been ill in the past year & 315 & 81,2 \\
\multicolumn{2}{c}{ Totals } & $\mathbf{3 8 8}$ & $\mathbf{1 0 0 , 0}$
\end{tabular}

e. Relationship between a House that applies Clean and Healthy Behavior with the occurrence of tubeculosis in Sekardangan Health Center

\begin{tabular}{|c|c|c|c|c|c|c|c|c|c|}
\hline \multirow{3}{*}{ No } & \multicolumn{8}{|c|}{ Kejadian TBC } & \multirow{3}{*}{$\begin{array}{c}\begin{array}{c}\text { Standardized } \\
\text { Coefficients }\end{array} \\
\text { Beta }(\beta)\end{array}$} \\
\hline & \multirow[t]{2}{*}{ Variable } & \multirow[t]{2}{*}{ Category } & \multicolumn{2}{|c|}{$\begin{array}{l}\text { There are } \\
\text { sick in the } \\
\text { last } 1 \text { year }\end{array}$} & \multicolumn{2}{|c|}{$\begin{array}{l}\text { No one has } \\
\text { been ill in the } \\
\text { past year }\end{array}$} & \multirow[t]{2}{*}{$\begin{array}{c}\text { Totals } \\
\text { (n) }\end{array}$} & \multirow[t]{2}{*}{$\%$} & \\
\hline & & & $\mathbf{N}$ & $\%$ & n & $\%$ & & & \\
\hline \multirow{2}{*}{1} & Healthy & Health & 3 & 0,8 & 216 & 55,7 & 219 & 56,4 & \multirow{2}{*}{.424} \\
\hline & Home & Not Health & 70 & 18,0 & 99 & 25,5 & 169 & 43,6 & \\
\hline \multirow{2}{*}{2} & & Yes & 0 & 0 & 202 & 52,1 & 202 & 52,1 & \multirow{2}{*}{.31} \\
\hline & PHBS & No & 73 & 18,8 & 113 & 29,1 & 186 & 47,9 & \\
\hline
\end{tabular}

Based on the above results, it can be said that partially healthy homes have a positive and significant relationship with the incidence of tuberculosis, while PHBS has a positive and significant relationship with the incidence of household tuberculosis in the Sekardangan Community Health Center. Based on the standardized beta coefficient $(\beta)$, it can be seen that the coefficient value on the healthy home variable is 0.424 , while the $\beta$ coefficient value on the PHBS variable is 0.310 . This shows that the healthy house variable is a significant and most influential 
variable on the TB incidence variable, assuming that the independent variable from the regression model is fixed.

\section{CONCLUSION}

The conclusions obtained from this study are:

a. From the results of data collection taken in the area of the Sekardangan Community Health Center there are $43.6 \%$ of households whose homes do not meet the requirements of a healthy home.

b. Households that did not have a clean and healthy life style were $47.9 \%$ of the total sample

c. Families with one family member who suffered from tuberculosis in the last 1 (one) year there were $18.81 \%$ of households in all samples

d. There is the influence of a healthy home on transmission and outbreak of TB, namely the level of strength of the relationship between the variables of a healthy home and the incidence of tuberculosis is 0.424 , meaning that the higher the healthy house, the lower the incidence of tuberculosis in the household

e. There is an influence of clean and healthy life behavior toward transmission and outbreaks of tuberculosis in the $\beta$ coefficient value on the PHBS variable is equal to 0.310 where it shows that the healthy home variable is a significant variable and most influential on the TB incidence variable

\section{SUGGESTION}

Suggestions obtained from this study are:

a. This research is expected to be able to add experience and knowledge, especially in terms of research that can be used in eradicating and controlling tuberculosis

b. This research is expected to be used as input for patients and households so that they always apply Clean and Healthy Behavior (PHBS) in their daily lives and in building houses to implement healthy house requirements so they can avoid infectious diseases, especially pulmonary tuberculosis.

\section{REFERENCES}

[1] Nizar Muhamad.2017. Eradication and Prevention of Tuberculosis. Sleman: Gosyen publishing

[2] Republic of Indonesia, Republic of Indonesia Minister of Health Decree No.829/Menkes/SK/VII/1999 concerning Housing Health Requirements

[3] TB Program Team. St.Carolus. 2017. "Tuberculosis Can Be Cured". Jakarta: Gramedia's Popular Library

[4] Republic of Indonesia, Regulation of the Minister of Health of the Republic of Indonesia Number 67 Year 2016 Regarding the Prevention of Tuberculosis

[5] Republic of Indonesia, 2007 Guide for Clean and Healthy Household Behavior

[6] Akbar, M. 2016. "Relationship between TB Patients' Knowledge and Family Prevention of Transmission Prevention Behavior in Sienjo Health Center". Journal of Nursing. Vol. IV (2): p. 104

[7] Directorate General of Disease Prevention and Control. 2019. Technical Guidelines for Implementing TB Case Findings in the Framework of World TB Day 2019. Jakarta: Ministry of Health, East Java Province 
[8] Febri Endra. 2017. "Healthy Paradigm". University of Muhammadiyah Malang, Malang

[9] Harsanto Budi, et al. 2012. Technical Guidelines for Healthy Home Valuation. Surabaya: Ministry of Health of East Java Province

[10]Juliansyah, Noor. 2011. Thesis Research Methodology, Thesis, Dissertation and Scientific Work. Jakarta: Kencana Prenada Media Group

[11]Republic of Indonesia, PP number 96 of 2018 concerning Requirements and Procedures for Population Registration and Civil Registration

[12]Puang, Maradona. (2016). The Influence of Environmental Factors, Health Services and Healthy Life Behavior on Resurgence of Tuberculosis in Surabaya. Thesis Not Published. Surabaya State University

[13] Ragsanagara, S.M. 2015. "Clean and Healthy Behavior as an Important Determinant of Health in Household Order in the City of Bandung". Journal of Public Health Sciences. Vol. 01 (1): p.30

[14] Wibisono A.F and A. Khairul Huda.2014. "Efforts to Increase Knowledge of Homes for Families". Journal of Innovation and Entrepreneurship. Vol.03 (1): p.17-20

[15] Wuryandari, E.F.L. 2017. "The Influence of Service Quality on Patient Decisions in Choosing Health Services at the Clinic of the Jama'ah Hajj Manisrenggo Foundation Klaten, Central Java". Sunan Kalijaga State Islamic University Yogyakarta 